\title{
Lepidoptera (Insecta) associated with soybean in Argentina, Brazil, Chile and Uruguay
}

\author{
Lepidópteros (Insecta) associados à cultura da soja na Argentina, Brasil, Chile e Uruguai
}

\begin{abstract}
Aline Carraro Formentini ${ }^{I}$ Daniel Ricardo Sosa-Gómez ${ }^{\text {II }}$ Silvana Vieira de Paula-Moraes ${ }^{\text {III }}$ Neiva Monteiro de Barros $^{\mathrm{I}}$ Alexandre Specht ${ }^{\mathrm{I}, \text { III }}$
\end{abstract}

\section{ABSTRACT}

The present research updates the systematic position and nomenclature of Lepidoptera associated with soybean crops in Argentina, Brazil, Chile and Uruguay. Scientific literature lists 69 species of Lepidoptera feeding on soybean plants. These species are representatives of the Superfamilies Noctuoidea (31), Pyraloidea (13), Hesperioidea (12), Tortricoidea (5), Geometroidea (5), and Bombycoidea (3). Diversity of Lepidoptera associated to crop, injury in different parts of the plant, and changes in species composition are discussed considering the changes in plant disease management, introduction of plants expressing Bt proteins, and the recent introduction of Helicoverpa armigera (Hübner) as a new crop pest.

Key words: caterpillars, inventory, taxonomy, systematic, lepidopterous pests.

RESUMO

O presente estudo atualiza a posição sistemática e a nomenclatura dos lepidópteros associados com a cultura da soja na Argentina, Brasil, Chile e Uruguai. A literatura cientifica relaciona 69 espécies de Lepidoptera cujas larvas se alimentam de soja. As espécies incluem representantes das Superfamílias Noctuoidea (31), Pyraloidea (13), Hesperioidea (12), Tortricoidea (5), Geometroidea (5), and Bombycoidea (3). A diversidade dos lepidópteros associados com a cultura, as injúrias em diferentes partes da planta e alterações na composição das espécies são discutidas considerando mudanças no manejo de doenças da cultura, a introdução de plantas expressando proteínas Bt e a recente introdução de Helicoverpa armigera (Hübner) como uma nova praga da soja.

Palavras-chave: lagartas, inventário, taxonomia, sistemática, lepidópteros-praga.

\section{INTRODUCTION}

Soybean is originated on the Asian coast, expanding first to Europe and later to the Americas. In Brazilian soils, the first crop was harvested in São Paulo in 1892 and produced only a few pounds of seed (EMBRAPA, 2004). In the 2013/2014 crop season, the largest production of soybean was in United States, with approximately 107 million tons (O'BRIEN 2014), Brazil with approximately 90 million tons (CONAB 2014), and Argentina with 56 million tons (INTA 2014).

Although soybean is an exotic plant, the crop has been established in different locations and increasing areas. Many arthropods species in the American continent gradually adapted to the crop, sometimes causing injury or becoming pests. These included Lepidoptera, such as Anticarsia gemmatalis Hübner, Chrysodeixis includens (Walker), Spodoptera cosmioides (Walker), and Spodoptera frugiperda (J.E. Smith) (MOSCARDI et al., 2012).

Several Lepidoptera associated with soybean crops have been reported in Brazil (e.g. SILVA et al., 1968; LINK \& TARRAGÓ,1974; BERTELS,1975; CORRÊA \& SMITH,1976; LOURENÇÃO et al.,1980) and in other countries in South America, including Argentina (PASTRANA, 2004), Uruguay (BIEZANKO et al., 1974; BENTANCOURT \& SCATONI, 2006) and Chile (ANGULO et al., 2008). The accurate identification of the species is extremely important for proper management and

\footnotetext{
IPrograma de Pós-graduação em Biotecnologia, Universidade de Caxias do Sul (USC), CP 1352, 95070-560, Caxias do Sul, RS, Brasil. E-mail: alexandre.specht@embrapa.br. "Corresponding author.

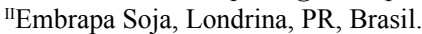

IIIEmbrapa Cerrados, Planaltina, DF, Brasil.
} 
to avoid economic losses (SOSA-GOMEZ et al., 2014). However, several aspects have affected the appropriate management of this group of pests: 1) changes in systematic positions and nomenclature (LAFONTAINE \& SCHMIDT, 2010); 2) changes detected in specific compositions of lepidopteran communities associated with soybean (GUEDES et al., 2010; SOSA-GÓMEZ et al., 2010; MOSCARDI et al., 2012); and 3) recent detection of Helicoverpa armigera (Hübner), which has economy impact in this crop (CZEPAK et al., 2013; EMBRAPA, 2013; SPECHT et al., 2013). This research is a review of reports of lepidoptera whose larvae were collected feeding on the soybean crop in Argentina, Brazil, Chile and Uruguay and also updates the systematic position and nomenclature of this taxonomic group. It is also discussed recent changes in species composition and abundance of the primary Lepidoptera associated with the crop, the changes in the management of soybean diseases, and the introduction of $\boldsymbol{H}$. armigera (Hübner) as a new crop pest.

\section{DEVELOPMENT}

Lepidoptera associated with soybean crop.

The bibliographic records indicate the occurrence of at least 69 species of Lepidoptera representatives of Tortricoidea, Pyraloidea (Table 1), Bombycoidea, Hesperioidea, Geometroidea (Table 2), and Noctuoidea (Table 3), whose larvae have been found feeding on soybean. The most species (44.9\%) belong to Noctuoidea, followed by Pyraloidea (18.8\%), Hesperioidea (17.4\%), Tortricoidea (7.3\%), Geometroidea (7.3\%), and Bombycoidea (4.3\%).

Despite the relative diversity of species, only a small number of studies have been devoted to identifying insects, including Lepidoptera at a species level (e.g. BIEZANKO et al., 1974; LINK \& TARRAGÓ, 1974; CORREIA \& SMITH, 1976). Generally, publications list A. gemmatalis, or the representatives of complexes Plusiinae Spodoptera, without species-level identification (e.g. MORAES et al., 1991; CIVIDANES \& YAMAMOTO, 2002).

Given the importance of identification for effective control of insects, many publications including identification manuals and other publications on insects associated with soybean have been published (SOSA-GÓMEZ et al., 2014; HOFFMANN-CAMPO et al., 2012). The lack of information about the diversity of insects indicates that association has not been made between diversity of insects and the "stability of agroecosystems". In addition, there is little information about the influences of regional physiography, temporal variations, and crop rotations (e.g. ALTIERI et al., 2005).
Usually, species-level identification is still done based exclusively on the morphology of adults (e.g. POGUE, 2002). The adult identification requires to rearing immature insects, which requires extensive resources, especially skilled labor. In addition, natural enemies and entomopathogens may affect the development and survival of immature insects making difficult to obtain adults. Alternatively, some studies has focused in species-level identification based on morphology of eggs, larvae, and pupae (e.g. PASSOA, 1991; POGUE, 2002; ANGULO et al., 2008; GOMEZROLIM et al., 2013). Another tool is the use of molecular markers (GOMEZ-ROLIM et al., 2013). In all options, the literature describing morphological or molecular characterization of lepidopterons associated to soybean does not include all species. These deficiencies are evident in all countries, especially in South America, which has biological mega-diversity (e.g. MARQUES \& LAMAS, 2006).

Over $80 \%$ of the species whose larvae have been reported feeding on soybean were recorded by the end of the 1970 decade (Tables 1-3), based on field collections and species-level identification (e.g. A.O. Angulo - Universidad de Concepción - Chile; A.M. Bertels - Embrapa Clima Temperado; C.M. Biezanko - Universidade Federal de Pelotas; D. Link - Universidade Federal de Santa Maria - Brasil and Pastrana in Argentina). These researchers have maintained entomological collections in their institutions which play an important role for several crops or for general entomology. Considering the great number of species reported in the early publications, the question remains if the diversity of Lepidoptera have decreased due to management, crop extensions, and insecticide pressure (e.g. ALTIERI et al., 2005), or is a problem of lack of studies focused on species-level identification (e.g. MARQUES \& LAMAS, 2006).

Anyway, the lack of taxonomists was directly related to the delay in the report of $\boldsymbol{H}$. armigera in Brazil, which has affected high value crops such as cotton and soybean (CZEPAK et al., 2013; EMBRAPA 2013; SPECHT et al., 2013). This indicates the vulnerability of Brazil and other countries in South America concerning the change of the status of native arthropod species, due to climate change, the invasion risk of quarantine pests, management, and the introduction of new crops or cultivars.

\section{Feeding behavior}

Traditionally, the insects associated with major crops, such as soybean, are grouped according to their feeding behavior. This classification allows damage estimates, appropriate sampling methods, and even 
Table 1 - Lepidoptera representatives of Tortricoidea and Pyraloidea associated with soybean and their respective feeding behavior.

\begin{tabular}{|c|c|c|}
\hline Higher taxa / species & Habits & References \\
\hline 1. Argyrotaenia fletcheriella (Koehler, 1939) & Polyphagous - leafroller & 3 \\
\hline 2. Argyrotaenia loxonephes (Meyrich, 1937) & Polyphagous - leafroller & 3 \\
\hline 3. Cydia fabivora (Meyrich, 1928) [Sin. Laspeyresia leguminis (Heinrich, 1943)] & Fabaceae $^{*}$ - borer. & 1 \\
\hline 4. Crocidosema aporema (Walsingham, 1914) & Fabaceae ${ }^{*}$ - borer & 1 \\
\hline 5. Strepsicrates smithiana (Walsingham, 1891) & Polyphagous - borer. & 2 \\
\hline 6. Dolichomia olinalis (Guenée, 1854) [Sin. Herculia infimbrialis Dyar, 1910)] & Oligophagous - leafroller & 2 \\
\hline 7. Dolichomia resectalis (Lederer, 1863) & Oligophagous - leafroller & 2 \\
\hline 8. Hypsopygia costalis (Fabricius, 1775) & Oligophagous - leafroller & 2 \\
\hline 9. Pococera vandella Dyar, 1914 & Fabaceae - leafroller & 2 \\
\hline 10. Elasmopalpus lignosellus (Zeller, 1848) & $\begin{array}{l}\text { Polyphagous - subterranean, } \\
\text { stems }\end{array}$ & 2 \\
\hline 11. Etiella zinckenella (Treitschke, 1832) & Oligophagous - borer & 1 \\
\hline 12. Helulla phidilealis (Walker, 1859) & Oligophagous - borer & 3 \\
\hline 13. Achyra bifidalis (Fabricius, 1794) & Polyphagous -leafroller & 3 \\
\hline 14. Achyra similalis (Gueneé, 1854) & Polyphagous - leafroller & 3 \\
\hline 15. Maruca vitrata (Fabricius, 1787) [Sin.: Maruca testulalis (Geyer, 1832)] & Oligophagous - borer & 2 \\
\hline 16. Omiodes indicata (Fabricius, 1775) & Fabacea $^{*}$ - leafroller & 1 \\
\hline 17. Salbia haemorrhoidalis Guenée 1854 & Oligophagous - leafroller & 2 \\
\hline 18. Samea ecclesialis Gueneé, 1854 & Polyphagous - leafroller & 3 \\
\hline
\end{tabular}

Current systematic: A - HEPPNER (1995); References: 1- SILVA et al. (1968); 2- BIEZANKO et al. (1974); 3- PASTRANA (2004); "Principally.

preliminary identification (HOFFMANN-CAMPO et al., 2012). Records of Lepidoptera, whose larvae were collected in soybean in South America, indicated that more than half of the species can be considered polyphagous $(52.2 \%)$; more than a quarter feed mainly on Fabaceae (27.5\%), one quarter mainly feed on Gramineae (5.8\%), and the other species feed on plants belonging to a few families, including Fabaceae or specifically soybean (14.5\%) (Tables 1 to 3 ).

Regarding feeding behavior, the larvae of most species (83.8\%) feed on foliage (including leaf eater, leafrollers, and pod eaters). Nearly half of these species $(48.5 \%)$ prefer to eat the leaves directly; a quarter $(25.0 \%)$ feed on foliage, but their larvae are also "leafrollers", joining the edges of the leaves with silk threads to build a shelter; $10.3 \%$ of the species that injury the foliage also consume the pods; six species are essentially borers $(8.8 \%)$; while only five $(7.4 \%)$ act as cutworms (Tables 1 to 3 ).

Different methods are demanded to efficiently sample caterpillars that act as leaf eater, leafrollers, borers, pod eater and cutworms. Because of this, it is convenient to consider the specific abundance of species with different feeding habits. This information directly affects the method of the sampling and the validation of the results (CORREA-FERREIRA, 2012).

Leaf eater caterpillars are the largest number of species and are often more abundant, but it has been registered the host plant compensation for their injuries, especially in the vegetative stage (CORREAFERREIRA, 2012). However, it is important to take in consideration the importance of the identification of the caterpillar due the different capacity for leaf consumption of different species (BEACH \& TODD, 1988; NAVA \& PARRA, 2002; FRANCO et al., 2014), their reproductive potential (MONTEZANO et al., 2013), and the spatial distribution of the different species in the host plant (PANSERA DE ARAÚJO et al., 1999).

The leafroller caterpillars, in early development, scrape the leaf parenchyma, making a net in the leaflets, which dry out. In other developmental stages, especially in the end of larval stage, the 
Table 2 - Lepidoptera representatives of Bombycoidea and Hesperioidea associated with soybean and their respective feeding behavior.

\begin{tabular}{|c|c|c|}
\hline Higher taxa / species & Habits & References \\
\hline \multicolumn{3}{|c|}{-Bombycoidea ${ }^{\mathrm{A}}-$ Saturniidae: Hemileucinae-- } \\
\hline 1. Automeris illustris (Walker, 1855) & Polyphagous - leaf eater & 4 \\
\hline 2. Hyperchiria incisa Walker, 1855 & Polyphagous - leaf eater & 2 \\
\hline 3. Leucanella memusae (Walker, 1855) & Polyphagous - leaf eater & 4 \\
\hline \multicolumn{3}{|c|}{-Hesperioide ${ }^{\mathrm{B}}$ - Pieridae: Coliadinae-1- } \\
\hline 4. Colias lesbia (Fabricius, 1775) & Fabaceae - leaf eater & 1 \\
\hline 5. Eurema albula (Cramer, 1775) & Fabaceae - leaf eater & 2 \\
\hline 6. Eurema deva (Doublday, 1847) & Fabaceae - leaf eater & 1 \\
\hline 7. Eurema elathea elathea (Cramer, 1777) & Fabaceae - leaf eater & 2 \\
\hline 8. Eurema elathea plataea (Felder, 1862) & Fabaceae - leaf eater & 1 \\
\hline 9. Eurema elathea flavescens (Chavannes, 1850) & Fabaceae - leaf eater & 8 \\
\hline \multicolumn{3}{|c|}{ Hesperioide ${ }^{\mathrm{C}}-$ Hesperiidae: Pyrginae- } \\
\hline 10. Chioides catillus catillus (Cramer, 1779) & Oligophagous - leaf eater & 1 \\
\hline 11. Epargyreus exadeus exadeus (Cramer, 1779) & Fabaceae - leaf eater & 2 \\
\hline 12. Urbanus proteus proteus (Linnaeus, 1758 ) & Fabaceae - leaf eater & 1 \\
\hline 13. Urbanus simplicius (Stoll, 1790) & Oligophagous - leaf eater & 2 \\
\hline 14. Urbanus teleus (Hübner, 1821) & Fabaceae - leaf eater & 2 \\
\hline 15. Urbanus zagorus (Plötz, 1880) & Fabaceae - leaf eater & 3 \\
\hline - & Ennominae-- & \\
\hline 16. Macaria abydata Guenée, [1858] & Fabaceae - leaf eater & 6 \\
\hline 17. Macaria regulata (Fabricius, 1775) & Oligophagous - leaf eater & 5 \\
\hline 18. Oxydia nimbata Guenée, [1857] & Polyphagous - leaf eater & 5 \\
\hline 19. Physocleora dimidiaria (Guenée; 1852) & Polyphagous - leaf eater & 9 \\
\hline 20. Stenalcidia vacillaria (Guenée, [1858]) & Polyphagous - leaf eater & 7 \\
\hline
\end{tabular}

Current systematic: A- HEPPNER (1996), LEMAIRE (2002); B- LAMAS (2004), BRABY et al. (2006); C- MIELKE (2005); D- SCOBLE (1999). References: 1- SILVA et al. (1968); 2- BIEZANKO et al. (1974); 3- LINK \& TARRAGÓ (1974); 4- BERTELS (1975); 5 CORRÊA \& SMITH (1976); 6- LOURENÇÃO et al. (1980); 7- PANIZZI \& FERREIRA (1980); 8- PASTRANA (2004); 9FORMENTINI (2009).

caterpillars interweave multiple leaves, forming a mass, which is partially consumed. In addition to reducing the photosynthetic tissue by depriving the leaves of sunlight, intense leaf feeding can consume the entire vegetal tissue, leaving only the veins. In addition, due to the behavior of rolling and joining multiple leaves, the caterpillars keep protected from insecticide sprays, making chemical control less effective (MOSCARDI et al., 2012).

The phyllophagous caterpillars of several species may also feed on pods. However, species such as representatives of Helicoverpa, Heliothis, and Spodoptera frequently consume soybean pods (PANIZZI et al. 2012). Although they represent only just over $10 \%$ of the species, these caterpillars have an economic impact on the crop. They directly affect productivity, and the plant cannot replace the lost pods. In addition, by staying at the bottom of the plant, they are less noticeable and sheltered, and thus again, less vulnerable to insecticide sprays.

Although the borer species represent only $9.1 \%$ (Tables $1-3$ ), their injury to the stems, flower buds, and pods cause economic impact since compromise the plant growth, This leads to the abortion of flowers and also favors plant pathogen colonization. In addition, they consume or damage the grains (PANIZZI et al., 2012).

Caterpillars of Noctuini Tribu, represented especially by Agrotis and Peridroma with cryptic species, have polyphagous habits and are cutting species. (BAUDINO \& VILLARREAL, 2007). Probably more species of cutworms than those reported in table 3 are responsible for damaging the early crops by reducing the plant stand.

Different temporal and spatial changes in species composition.

As previously described, most studies devoted to identify the entomofauna associated with soybean crops were done before 1980. That is when most soybean was cultivated in southern Brazil and Argentina, in a cropping system which was rotated with winter wheat and summer soybean crops. Since 
Table 3 - Lepidoptera representatives of Noctuoidea associated with soybean and their respective feeding behavior.

\begin{tabular}{|c|c|c|}
\hline Higher taxa / species & Habits & References \\
\hline \multicolumn{3}{|c|}{ - } \\
\hline 1. Paracles cajetani (Rothschild, 1910) & Polyphagous - leaf eater & 4 \\
\hline 2. Paracles vulpina (Hübner, [1825]) & Polyphagous - leaf eater & 6 \\
\hline 3. Spilosoma virginica (Fabricius, 1798) & Polyphagous - leaf eater & 6 \\
\hline \multicolumn{3}{|c|}{ } \\
\hline 4. Anticarsia irrorata Fabricius, 1781 & Fabaceae - leaf eater & 6 \\
\hline 5. Anticarsia gemmatalis Hübner, 1818 & Fabaceae - leaf eater & 1 \\
\hline 6. Mocis latipes Guenée, 1852 & 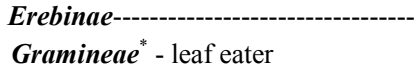 & 1 \\
\hline \multicolumn{3}{|c|}{ - } \\
\hline 7. Phalaenophana eudorealis (Guenée, 1854) & Oligophagous - leaf eater & 4 \\
\hline 8. Rejectaria pharusalis (Walker, [1859] & Polyphagous - leaf eater & 4 \\
\hline $\begin{array}{l}\text { 9. Condica mobilis (Walker, [1857]) [Sic.: Condica sutor } \\
\text { (Guenée, 1852)] }\end{array}$ & $\begin{array}{l}\text { Condicinae-------------- } \\
\text { Polyphagous - leaf eater }\end{array}$ & 8 \\
\hline 10. Autoplusia egena (Guenée, 1852) & $\begin{array}{l}\text { Plusiinae----------------- } \\
\text { Polyphagous - leaf eater }\end{array}$ & 2 \\
\hline 11. Ctenoplusia oxygramma (Geyer, 1832) & Polyphagous - leaf eater & 2 \\
\hline 12. Enigmogramma admonens (Walker, [1858]) & Soybean - leaf eater & 3 \\
\hline $\begin{array}{l}\text { 13. Chrysodeixis includens (Walker, [1858]) [Sin. Plusia } \\
\text { oo (Stoll, 1782)] }\end{array}$ & Polyphagous - leaf eater & 2 \\
\hline 14. Trichoplusia ni Hübner, [1803] & Polyphagous - leaf eater & 4 \\
\hline 15. Rachiplusia nu Guenee, 1852 & Polyphagous - leaf eater & 1 \\
\hline 16. Helicoverpa armigera (Hübner, 1809) & 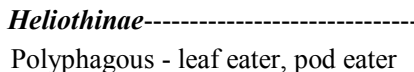 & 9 \\
\hline 17. Helicoverpa gelotopoeon (Dyar, 1921) & Polyphagous - leaf eater, pod eater & 6 \\
\hline 18 Helicoverpa zea (Boddie, 1850) & Polyphagous - leaf eater, pod eater & 2 \\
\hline 19. Heliothis virescens (Fabricius, 1777) & Polyphagous - leaf eater, pod eater & 6 \\
\hline 20. Agrotis gypaetina Guenée, 1852 & $\begin{array}{l}\text { Noctuinae--------------- } \\
\text { Polyphagous - cutworm }\end{array}$ & 7 \\
\hline 21. Agrotis ipsilon (Hufnagel, 1766) & Polyphagous - cutworm & 4 \\
\hline 22. Agrotis malefida Guenée, 1852 & Polyphagous - cutworm & 6 \\
\hline 23. Dargida meridionalis (Hampson, 1905) & Gramineae $^{*}$ - leaf eater & 4 \\
\hline 24. Elaphria agrotina (Gueneé, 1852) & Polyphagous - leaf eater & 2 \\
\hline 25. Mythimna adultera (Schaus, 1894) & Gramineae $^{*}$ - leaf eater & 2 \\
\hline 26. Mythimna sequax (Franclemont, 1951) & Graminea $^{*}$ - leaf eater & 1 \\
\hline 27. Peridroma saucia (Hübner, 1808) & Polyphagous - cutworm & 8 \\
\hline 28. Spodoptera albula (Walker, 1857b) & Polyphagous - leaf eater & 5 \\
\hline $\begin{array}{l}\text { 29. Spodoptera cosmioides (Walker, 1858) [Sic.: } \\
\text { Spodoptera latifascia (Walker, 1856) }\end{array}$ & Polyphagous - leaf eater, pod eater & 4 \\
\hline 30. Spodoptera eridania (Stoll, 1782) & Polyphagous - leaf eater, pod eater & 3 \\
\hline 31. Spodoptera frugiperda (J.E. Smith, 1797) & Polyphagous - leaf eater, pod eater & 1 \\
\hline
\end{tabular}

Current systematic: A- LAFONTAINE \& SCHMIDT (2010). References: 1- SILVA et al. (1968); 2- BIEZANKO et al. (1974); 3- LINK \& TARRAGÓ (1974); 4- BERTELS (1975); 5- POGUE (2002); 6- PASTRANA (2004); 7- BENTANCOURT \& SCATONI (2006); 8FORMENTINI (2009); 9- EMBRAPA (2013). "Principally.

1980, soybean has spread to the warmer regions of both countries and also Paraguay, increasing significantly the production areas, in a cropping system with rotation with other crops, such as cotton and corn. This expansion and intensification of soybean production, rotated with other major annual crops, certainly influenced the specific composition of associated species (EMBRAPA, 2004). Another aspect that may influence the potential of different species to establish is the architecture of the plant and plant spacing, which has led to a reduction in branching and concentration of the pods on the main stem (MAUAD et al., 2010). 
In addition, different events demand the modification of established management systems for crops in large areas in Brazil due to the changing species composition of the entomofauna and the dynamics of the main noctuids associated with these crops. The introduction of Asian soybean rust caused by the fungus Phakopsora pachyrhizi Syd. \& P. Syd., in the 2001/02 harvest (YORINORI et al., 2005), required preventive and intensive use of fungicides in the crop. This reduced the natural occurrence of the entomopathogenic fungus Metarhizium rileyi (Farlow) Kepler, Rehner \& Humber, which consequently affect the natural biological control and changed the noctuids species composition (MOSCARDI et al., 2012).

The latest generation of pest control employs genes expressing proteins in plant species from the bacterium Bacillus thuringiensis (Berliner) [Bt]. For caterpillar control, this technology has been widely adopted in Brazil in corn and cotton, with recent adoption (2013/14 crop) in soybean. The reduction in insecticide applications, which consequently could favor natural biological pest control, has been listed as one of the benefits of plants expressing the Bt toxin (HELLMICH et al., 2008). In the US, it has been documented the reduction of the pest Ostrinia nubilalis (Hübner) in corn and consequently the economic benefits of introducing Bt plants (HUTCHISON et al., 2010). On the other hand, the change in the status of secondary pests may represent a problem. The survival of secondary pest species may increase, due to decreasing and even elimination of chemical control in the agroecossystem, which can be aggravated by eliminating competition existed prior to the control of key pests by Bt. This considerations highlight the importance of the knowledge of all species present in the soybean agroecosystem in a new scenario of $\mathrm{Bt}$ technology. Another factor to be considered in the adoption of Bt technology is the risk of the development of resistance in populations of target pests (e.g. TABASHNIK, 2013; FARIAS et al., 2014). The Bt toxin is expressed in high dose in the plant, with high exposure and high persistence during the whole crop cycle. These aspects are considered advantages of the technology. However, they also represent a selection pressure for some target caterpillars to survive to the $\mathrm{Bt}$ technology. As a result, there is a risk of establishing resistance in future generations of populations of some species, in which the toxin can lose the desired control. Insect resistance management (IRM) measures are required in order to deal with this risk of resistance.

The recent detection of $\boldsymbol{H}$. armigera (CZEPAK et al., 2013; EMBRAPA 2013; SPECHT et al., 2013), previously not reported in the American continent become another important aspect for agriculture in Brazil. H. armigera is reported to feed in more than 300 native and cultivated host plants (LIU et al., 2004). Many of these plants are used to produce food, fiber, and oils in Brazil. In addition, the caterpillars prefer the reproductive parts of the plants, but also injury the vegetative structures with a high capacity of economic impact (ZALUCKI et al., 1986).

\section{CONCLUSION}

There are at least 69 representatives of Lepidoptera, whose larvae have already been reported, that feed on soybean in Argentina, Brazil, Chile, and Uruguay. Most species belong to Noctuoidea and are leaf eaters and polyphagous caterpillars.

Most studies on soybean do not present a species-level identification, due to the lack of publications on morphology and taxonomy of Lepidoptera, especially related to immature morphology description.

In addition to the species-level identification, it is necessary to preserve vouchers specimens which document researches and can also indicate temporal and spatial variations of the species composition. This is particularly relevant in cases of the introduction of exotic species or other changes in the agroecosystem.

\section{ACKNOWLEDGMENTS}

The first author would like to thank Coordenação de Aperfeiçoamento de Pessoal de Nível Superior (CAPES) for the master's fellowship.

\section{REFERENCES}

ALTIERI, M.A. et al. Manipulating vineyard biodiversity for improved insect pest management: case studies from northern California. International Journal of Biodiversity Science and Management, v.1, p.1-13, 2005. Available from: <http://agroeco.org/wp-content/ uploads/2010/09/Int.J.Biodiv-Mgmt.pdf>. Accessed: Jun. 10, 2014.

ANGULO, A.O. et al. Estados inmaduros de lepidópteros noctuidos de importância econômica, agrícola y forestal em Chile (Lepidoptera: Noctuidae). Concepcion-Chile: Impresso Siglo Veintiuno. 2008. 154p.

BAUDINO, E.; VILLARREAL, D. Orugas cortadoras que dañan cultivos de consecha gruesa y pasturas de alfalfa en la región oriental de la Provincia de La Pampa. Revisión bibliográfica. Revista de la Universidad de Agronomía - La Pampa, v.18, n.1/2, p. 11-57, 2007.

BEACH, R.M.; TODD, J.W. Foliage consumption and developmental parameters of the soybean looper and the velvetbean caterpillar (Lepidoptera: Noctuidae) reared on susceptible and resistant soybean genotypes. Journal of Economic Entomology, v.81, n.1, p.310-316, 1988 .

BENTANCOURT, C.M.; SCATONI, I.B. Lepidopteros de importancia económica en Uruguay: reconocimiento, biología y 
daños de las plagas agrícolas y forestales. Montevideo: Hemisfério Sur, 2006. $437 \mathrm{p}$.

BERTELS, A.M. Insetos-pragas da soja e seu combate. Pelotas: Embrapa, 1975. 33p. (Boletim Técnico, 100).

BIENZANKO, C.M. et al. Plantas y otras sustancias alimenticias de las orugas de los lepidopteros uruguayos. Revista do Centro de Ciências Rurais, v.4, n.2, p.107-148. 1974

BRABY, M.F. et al. Molecular phylogeny and systematics of the Pieridae (Lepidoptera: Papilionoidea): Higher classification and biogeography. Zoological Journal of the Linnean Society, v.147, p.239-275, 2006.

CIVIDANES, F.J.; YAMAMOTO, F.T. Pragas e inimigos naturais na soja e no milho, cultivados em sistemas diversificados Scientia Agrícola, v.59, n.4, p.683-687, 2002. Available from: $<$ http://www.scielo.br/scielo.php? script $=$ sci_arttext\&pid $=$ S0103-90162002000400010 $>$. Accessed: Sept. 10, 2013. doi: $10.1590 / \mathrm{S} 0103-90162002000400010$

CONAB. Acompanhamento da safra brasileira de grãos. V.1. Safra 2013/2014, núm. 4 - Quarto levantamento. 72p. ISSN 2318-6852. Available from: <http://www.conab.com.br $>$. Online. Accessed: Jan. 10, 2015.

CORRÊA, B.S.; SMITH, J.G. Occurrence of Geometridae on soybeans in Paraná, Brazil. Florida Entomologist, v.59, n.2, p.223, 1976. Available from: < http://journals.fcla.edu/flaent/ article/view/57093/54772>. Accessed: Jul. 13, 2013.

CORREA-FERREIRA, B.S. Amostragem de pragas da soja. In: HOFFMAN-CAMPO, C.B. et al. Soja - Manejo integrado de insetos e outros artrópodes-praga. Brasília: Embrapa, 2012. Cap.9, p.631-672.

CZEPAK, C. et al. Primeiro registro de ocorrência de Helicoverpa armigera (Hübner) (Lepidoptera: Noctuidae) no Brasil. Pesquisa Agropecuária Tropical, v.43, n.1, p.110-113, 2013. Available from: <http://www.scielo.br/pdf/pat/v43n1/15.pdf $>$. Accessed: Ago. 10, 2014. doi: 10.1590/S1983-40632013000100015.

EMBRAPA. Tecnologia de produção de soja - Região Central do Brasil, 2005. Londrina: Embrapa Soja, Embrapa Cerrados, Embrapa Agropecuária Oeste, Fundação Meridional. 2004. 239p. (Sistemas de Produção / Embrapa Soja, n.6).

EMBRAPA. Nota técnica sobre resultado do trabalho inicial de levantamento da lagarta do gênero Helicoverpa - detecção da espécie Helicoverpa armigera no Brasil. Planaltina: Embrapa Cerrados e Embrapa Soja, 2013. 2p. [Nota técnica, 22 de março de 2013]. Available from: <http://www.researchgate. net/home.Home.html>. Accessed: Mar. 23, 2015. doi: 10.13140/ RG.2.1.294667685.

FARIAS, J.R. et al. Field-evolved resistance to Cry1F maize by Spodoptera frugiperda (Lepidoptera: Noctuidae) in Brazil. Crop Protection, v.64, p.150-158, 2014. Available from: <http://www. sciencedirect.com/science/article/pii/S026121941400204X $>$. Accessed: Jun. 04, 2014. doi: 10.1016/j.cropro.2014.06.019.

FORMENTINI, A.C. Lepidópteros associados à cultura da soja: diversidade e parasi-tismo natural por insetos e fungos entomopatogênicos. 2009. 58f. Dissertação (Mestrado em Biotecnologia) - Programa de Pós-graduação em Biotecnologia,
Universidade de Caxias do Sul, RS. Available from: $<$ http://tede.ucs. br/tde busca/arquivo.php?codArquivo=349>. Accessed: Jun. 21, 2010.

FRANCO A.A. et al. Preferencia alimentar de Anticarsia gemmatalis Hübner (Lepidoptera: Noctuidae) por cultivares de soja. Científica, v.42, n.1, p.32-38, 2014. Available from: <http:// www.cientifica.org.br/index.php/cientifica/article/view/19845529.2014v42n1p032-038/270>. Accessed: May 17, 2014

GOMEZ-ROLIM, A.A.S. et al. Morphological and molecular characterization of the eggs of some noctuid species associated with soybean in Brazil. Annals of the Entomological Society of America, v.106, n.5, p.643-651, 2013. Available from: <http:// www.bioone.org/doi/full/10.1603/AN13049>. Accessed: Oct. 11, 2013. doi: 10.1603/AN13049.

GUEDES, J.V.C. et al. Nova dinâmica de lagartas na soja. Cultivar Grandes Culturas, v.139, p.24-26, 2010. Available from: <http:// www.grupocultivar.com.br>. Accessed: Jun. 23, 2012.

HELLMICH, R.L. et al. The present and future role of insectresistant genetically modified maize in IPM. In: ROMEIS, J. et al. (Eds). Integration of insect-resistant genetically modified crops within IPM programs. Netherland: Springer, 2008. Cap.5, p.119-158.

HEPPNER, J.B. Atlas of Neotropical Lepidoptera. Checklist: Part 2. Hyblaeoidea - Pyraloidea - Tortricoidea. Gainesville: Association for Tropical Lepidoptera / Scientific Publishers, 1995. 243p.

HEPPNER, J.B. Atlas of Neotropical Lepidoptera. Checklist: Part 4B. Drepanoidea - Bombycoidea - Sphingoidea Gainesville: Association for Tropical Lepidoptera/Scientific Publishers, 1996. 87p.

HOFFMANN-CAMPO, C.B. et al. Soja - manejo integrado de Insetos e outros Artrópodes-praga. Brasília: Embrapa, 2012. 859p.

HUTCHISON, W.D. et al. Area wide suppression of European corn borer with Bt maize reaps savings to non-Bt maize growers. Science, v.330, n.6001, p.222-225, 2010. Available from: <http:// www.sciencemag.org/content/330/6001/222>. Accessed: Ago. 21, 2013. doi: $10.1126 /$ science. 1190242

INTA. INTA informa - soja: radiografia de la última campaña. Online. Available from: $<$ http://intainforma.inta.gov.ar/?p=22897>. Accessed: Jan. 27, 2015.

LAFONTAINE, J.D.; SCHMIDT, B.C. Annotated check list of the Noctuoidea (Insecta, Lepidoptera) of North America north of Mexico. ZooKeys, n.40, n.esp.6, p.1-239, 2010. Available from: $<$ http://dx.doi. org/10.3897/zookeys.40.414>. Accessed: Sept. 14, 2011.

LAMAS, G. Checklist: part 4A. Hesperioidea - Papilionoidea. In: HEPPNER, J.B. (Ed.). Atlas of Neotropical Lepidoptera. Gainesville: Association for Tropical Lepidoptera/ Scientific Publishers, 2004. 439p.

LEMAIRE, C. The Saturniidae of America - Hemileucinae. Keltern: Goecke \& Evers, 2002. 3v. 1388p.

LINK, D.; TARRAGÓ, M.F.S. Desfolhamento causado por lagartas em soja. Revista do Centro de Ciências Rurais, v.4, n.2, p.247-252, 1974. Available from: <http://squeeze.cpd.ufsm.br/revista new/ojs/ index.php/RCCCR/article/view/109/109>. Accessed: Oct. 19, 2012. 
LIU, Z. et al. Life table studies of the cotton bollworm, Helicoverpa armigera (Hübner) (Lepidoptera: Noctuidae), on different host plants. Environmental Entomology, v.33, n.6, p.1570-1576, 2004. Available from: <http://dx.doi. org/10.1603/0046-225X-33.6.1570>. Accessed: Jul. 11, 2012. doi: 10.1603/0046-225X-33.6.1570.

LOURENÇÃO, A.L. et al. Ocorrência de Semiothisa abydata (Guenée) (Lepidoptera: Geometridae) em soja no estado de São Paulo. Bragantia, v.39, n.1, p.247-248, 1980. Accessed: Apr. 23, 2012. Available from: <http://www.scielo.br/pdf/brag/ v39n1/33.pdf $>$. Accessed: Jun. 14, 2013. doi: 10.1590/S000687051980000100033 .

MARQUES, A.C.; LAMAS, C.J.E. Taxonomia zoológica no Brasil: estado da arte, expectativas e sugestões de ações futuras. Papéis Avulsos de Zoologia, v.46, n.13, p.139-174, 2006. Available from: $<$ http://www.revistas.usp.br/paz/article/view/33671>. Accessed: Jan. 22, 2013. doi: 10.1590/S0031-10492006001300001.

MAUAD, M. et al. Influência da densidade de semeadura sobre características agronômicas na cultura da soja. Agrarian, v.3, n.9, p.175-181, 2010. Available from: <http://www.periodicos. ufgd.edu.br/index.php/agrarian/article/view/75/649>. Accessed: Oct. 08, 2012.

MIELKE, O.H.H. Catalogue of the American Hesperioidea: Hesperiidae (Lepidoptera). Curitiba: Sociedade Brasileira de Zoologia, 2005. 6v. 1536p.

MONTEZANO, D.G. et al. Immature stages of Spodoptera albula (Walker) (Lepidoptera: Noctuidae): Developmental parameters and host plants. Anais da Academia Brasileira de Ciências, v.85, n.1, p.271-284, 2013. Available from: <http://www.scielo.br/pdf/ aabc/v85n1/0001-3765-aabc-85-01-271.pdf $>$. Accessed: Oct. 11, 2013. doi: 10.1590/S0001-37652013000100013.

MORAES, R.R. et al. Flutuação populacional de Plusiinae e Anticarsia gemmatalis Hübner, 1818 (Lepidoptera: Noctuidae) em soja no Rio Grande do Sul. Pesquisa Agropecuária Brasileira, v.26, n.1, p.51-56, 1991. Available from: <http://seer.sct.embrapa. br/index.php/pab/article/view/3161>. Accessed: Ago. 04, 2012.

MOSCARDI, F. et al. Artrópodes que atacam as folhas da soja. In: HOFFMAN-CAMPO, C.B. et al. Soja - manejo integrado de insetos e outros artrópodes-praga. Brasília: Embrapa, 2012. Cap.4, p.213-334.

NAVA, D.E.; PARRA, J.R.P. Development and soybean leaf consumption by Urbanus proteus proteus (L.). Scientia Agricola, v.59, n.4, p.661-663, 2002. Available from: <http://www.revistas. usp.br/sa/article/view/21781>. Accessed: Oct. 16, 2013. doi: 10.1590/S0103-90162002000400006.

O'BRIEN, D. Grain market outlook - Soybean market outlook in December 2014. Extension Grain Economist, Department of Agricultural Economics, Kansas State University. Online. Available from: <http://www.agmanager.info/marketing/outlook/ newletters/Soybeans.asp>. Accessed: Jan. 27, 2015.

PANIZZI, A.R.; FERREIRA, B.S.C. Geometrídeos em soja: flutuação estacional e ressurgência após o uso de inseticidas.
Pesquisa Agropecuária Brasileira, v.15, n. 2, p.159-161, 1980. Available from: <http://seer.sct.embrapa.br/index.php/pab/article/ view/16495/10775>. Accessed: Oct. 12, 2012.

PANIZZI, A.R. et al. Insetos que atacam vagens e grãos. In: HOFFMANCAMPO, C.B. et al. Soja - manejo integrado de insetos e outros artrópodes-praga. Brasília: Embrapa, 2012. Cap.5, p.335-420.

PANSERA DE ARAUJO, M.C.G. et al. Characterization and biological properties of embryonic stages of four Noctuidae (Lepidoptera). Annals of the Entomological Society of America, v.92, n.1, p.130-138, 1999.

PASSOA, S. Color identification of economically important Spodoptera larvae in Honduras (Lepidoptera: Noctuidae). Insecta Mundi, v.5, n.3-4, p.185-195, 1991. Available from: $<\mathrm{http} / / /$ digitalcommons.unl.edu/insectamundi/414>. Accessed: Oct. 03, 2012.

PASTRANA, J.A. Los lepidoteros argentinos: sus plantas hospedadoras y otros substratos alimenticios. Buenos Aires: Sociedad Entomológica Argentina. 2004. 350p.

POGUE, G.M. A world revision of the genus Spodoptera Guenée (Lepidoptera: Noctuidae). Memoirs of the American Entomological Society, v.43, p.1-202, 2002.

SCOBLE, M.J. Geometrid moths of the world: a catalogue (Lepidoptera: Geometridae). Collingwood, Victoria: CSIRO 1999. 2v. 1016 p.

SILVA, A.G.D'A. et al. Quarto catálogo dos insetos que vivem nas plantas do Brasil, seus parasitos e predadores. Parte II, $1^{\circ}$ tomo. Insetos, hospedeiros e inimigos naturais. Rio de Janeiro, Ministério da Agricultura, 1968. 622p.

SOSA-GÓMEZ, D.R. et al. Manual de identificação de insetos e outros invertebrados da cultura da soja. Londrina: Embrapa Soja. 2014. 90p. (Série Documentos 269).

SPECHT, A. et al. Helicoverpa armigera (Lepidoptera: Noctuidae: Heliothinae) no Brasil: Identificação morfológica e molecular. Pesquisa Agropecuária Brasileira, v.48, n.6, p.689-692, 2013. Available from: <http://www.scielo.br/pdf/pab/ v48n6/15.pdf>. Accessed: Sep. 15, 2013. doi: 10.1590/S0100204X2013000600015.

TABASHNIK, B.E. et al. Insect resistance to Bt crops: lessons from the first billion acres. Nature Biotechnology, v.31, p.510-521, 2013. Available from: <http://www.nature.com/nbt/journal/v31/n6/full/ nbt.2597.html>. Accessed: Jun. 14, 2014. doi: 10.1038/nbt.2597.

YORINORI, J.T. et al. Epidemics of soybean rust (Phakopsora pachyrhizi) in Brazil and Paraguay from 2001 to 2003. Plant Disease, v.89, n.6, p.675-677, 2005. Available from: <http:// apsjournals.apsnet.org/doi/pdf/10.1094/PD-89-0675>. Accessed: Oct. 19, 2012. doi: 10.1094/PD-89-0675.

ZALUCKI, M.P. et al. The biology and ecology of Heliothis armigera (Hübner) and $\boldsymbol{H}$. puntigera Wallengren (Lepidoptera: Noctuidae) in Australia: What we know? Australian Journal of Zoology, v.34, n.6, p.779-814, 1986. 